\title{
Menumbuhkan Integritas melalui Karakter Anti Korupsi untuk Mempersiapkan Remaja menjadi Agen Perubahan
}

\author{
Amelia Naim Indrajaya ${ }^{1 *}$, Yulita Fairina Susanti ${ }^{2}$, \\ Rudy Eddy Widjaja ${ }^{3}$, Heryudi $^{4}$, Candra Setianto ${ }^{5}$, Juliana $^{6}$ \\ ${ }^{123456}$ Sekolah Tinggi Manajemen IPMI, DKI Jakarta 12750, Indonesia \\ Author E-mail: amelia.naim@ipmi.ac.id
}

\begin{abstract}
A B S T R A K
Sedari awal tahun 2004 dan 2005 lembaga konsultan Political and Economic Risk Consultancy (PERC) menyatakan dari hasil survei bahwa Indonesia masih merupakan negara yang paling korup di antara 12 negara Asia. Meski telah dilakukan berbagai upaya untuk memberantas korupsi, di tahun 2005, Indonesia masih termasuk dalam tiga teratas negara terkorup di Asia. Kenyataan miris inilah yang terus memotivasi seluruh elemen bangsa untuk menanamkan karakter yang berintegritas untuk mencegah terulangnya masalah korupsi ini di Indonesia.

Ditinjau dari praktek dan pengalaman dari negara lain yang relatif berhasil mengatasi korupsi, ditemukan bahwa cara yang paling efektif adalah melalui media pendidikan. Tentu saja aspek penegakan hukum adalah hal yang penting, namun untuk pencegahan, Pendidikan Anti Korupsi amat diperlukan. Program kampanye anti korupsi ini menerapkan pendekatan yang menumbuhkan kesadaran untuk menjadi agen perubahan dengan menerapkan sembilan nilai integritas yaitu Jujur, Peduli, Sederhana, Tanggung Jawab, Kerja Keras, Mandiri, Disiplin, Berani dan Adil. Melalui program pengabdian masyarakat ini para remaja diajak untuk mulai berkomitmen untuk menyebarkan konsep integritas melalui perilaku kehidupan sehari-hari dan melakukan kampanye anti korupsi melalui sosial media untuk Indonesia yang lebih bersih.
\end{abstract}

Kata Kunci: Anti Korupsi, Integritas, Change-Maker, Area of Control, Area of Influence.

\section{A B S T R A C T}

From the beginning of 2004 and 2005 the Political and Economic Risk Consultancy (PERC) consultant agency had stated based on the survey results that Indonesia was still the most corrupt country among 12 Asian countries. Despite various efforts to eradicate corruption, in 2005, Indonesia was still among the top three of the most corrupt countries in Asia. This sad reality is what continues to motivate all elements of the nation to instill a character with integrity to prevent the recurrence of this corruption problem in Indonesia.

Judging from the practices and experiences of other countries that are relatively successful in overcoming corruption, it is found that the most effective way is through the media of education. Of course, the aspect of law enforcement is important, but for the prevention of Anti-Corruption, education is very much needed. 
This anti-corruption campaign program implements an approach that raises awareness to become agents of change by implementing nine integrity values, namely Honest, Caring, Humble, Responsible, Hard Work, Independent, Disciplined, Courageous and Fair. Through this community engagement activities, teenagers are invited to start committing to spreading the concept of integrity through daily life behavior and carrying out anti-corruption campaigns through social media for a cleaner Indonesia.

Key word: Presentation Skill, Moment of Truth, Empathy, Assertiveness.

Copyright $(\subset 2021$ Authors. This is an open access article distributed under the Creative Commons Attribution License, which permits unrestricted use, distribution, and reproduction in any medium, provided the original work is properly cited.

\section{PENDAHULUAN}

Korupsi di Indonesia berkembang dan menggurita di berbagai tingkatan. Di mulai dari tingkat di tataran sistemik, di tataran korporat, sampai pada tataran individual. Bahkan praktek ini telah menjadi suatu kebiasaan, sehingga merupakan suatu keanehan bila tidak ikut-ikutan melakukan praktek korupsi yang sama. Hal ini dapat terlihat dari sistem pengutipan yang terlihat di berbagai lini sampai pada kasus suap dan lobi tingkat tinggi yang besaran angka yang terlibat sudah amat tinggi. Berdasarkan penilaian dari Badan International Transparancy International, Indeks Persepsi korupsi Indonesia di tahun 2019 adalah 40 dari skala $0-100$, di mana nilai 100 adalah paling bersih. Indonesia menduduki peringkat 85 dari 180 negara.

Korupsi di Indonesia merupakan salah satu tindakan atau perbuatan yang merugikan dan harus segera dilakukan pencegahan dan penindakan secara tegas dan serius. Berdasarkan undang-undang no 31 tahun 1999 tentang pemberantasan tindak korupsi yang saat ini sudah di perbaharui menjadi undangundang nomor 20 tahun 2001, tindak pindana korupsi terjadi saat seseorang melawan hukum yaitu saat seseorang melakukan upaya untuk memperkaya diri sendiri atau orang lain / perusahaan yang akan merugikan keuangan negara dan / atau perekonomian negara.

Wijayanto (2010) mengatakan bahwa ada empat pendekatan yang paling banyak digunakan untuk mengeradikasi korupsi yang diterapkan di berbagai sudut belahan dunia, yaitu:

1. Pendekatan Pengacara (Lawyer approach).
Pendekatan pencegahan korupsi ini dilakukan melalui upaya penegakan hukum. Semua celah yang memungkinkan timbulnya tindak korupsi dieliminasi, serta dipastikan bahwa aparat hukum benar-benar bertanggung jawab. Memang pendekatan ini cenderung secara cepat sudah terlihat dampaknya dengan pengungkapan kasus-kasus korupsi, namun membutuhkan biaya yang besar. Masalah tambahan muncul, karena di Indonesia justru korupsi yang parah terjadi di kalangan penegak hukum (Soraya, 2015).

2. Pendekatan Bisnis (Business approach). Pendekatan ini adalah tindak pencegahan dengan memberikan para karyawan insentif yang cukup dalam bekerja. Insentif ini disesuaikan dengan besarnya kontribusi dan kinerja pegawai dalam bekerja. Diharapkan terjadi persaingan yang sehat di antara para karyawan. Pemberian insentif yang menguntungkan ini diharapkan juga dapat menghilangkan kebutuhan untuk melakukan korupsi.

3. Pendekatan Pasar atau Ekonomi (Market or Economist approach). Pada pendekatan ini diciptakan kompetisi antar pegawai agar masing-masing memberikan kinerja yang terbaik dan memberikan pelayanan yang terbaik. Nantinya akan dipilih pegawai yang paling bersih dan tinggi kualitas pelayanannya. Hal ini diharapkan akan menciptakan karakter pegawai yang berlomba-lomba untuk memberikan pelayanan yang terbaik.

4. Pendekatan Budaya (Cultural approach). Pada pendekatan budaya ini, pendidikan memegang peranan yang amat penting. 
Melalui pendidikan dengan beragam bentuk dan proses, dibangun karakter anti korupsi yang kuat. Pendekatan melalui pengembangan budaya dan karakter yang membentuk integritas ini diharapkan akan dapat mengatasi masalah korupsi secara efektif. Meskipun begitu pendekatan ini membutuhkan waktu yang lama untuk dapat mengetahui dampak keberhasilannya. Keuntungan dari pendekatan ini adalah biaya yang dibutuhkan tidak begitu besar, dan hasilnya akan berdampak besar dan berjangka panjang di masa depan.

Upaya pengabdian masyarakat ini adalah pengembangan dari bulir terakhir yang dijabarkan di atas. Dengan melakukan program pengabdian masyarakat ini remaja sebagai target partisipan diajak menjadi agen perubahan dengan membentuk karakter berintegritas melalui sikap jujur, peduli, sederhana, tanggung jawab, kerja keras, berani, adil, mandiri dan disiplin dan mempromosikannya kepada lingkungan sekitar dan masyarakat luas. Pelatihan dilaksanakan dengan pendekatan presentasi yang menginspirasi sehingga menggugah kesadaran para remaja untuk bertindak nyata sebagai agen perubahan (Naim, 2020). Pendekatan spiritual juga digunakan agar timbul pemahaman akan peran manusia sebagai wakil sang Khalik di muka bumi untuk memimpin dan mempengaruhi sesama ke arah kebaikan (Naim, Daryanto, Syahrifa, 2019).

\section{Identifikasi dan Perumusan Masalah}

Orientasi dari pendidikan anti korupsi ini bersifat jangka panjang sebagai bagian dari penggemblengan dari proses pengembangan dan pendidikan karakter. Pendidikan ini dimulai dari usia sedini mungkin, di tataran keluarga, sampai kepada pendidikan dasar hingga pendidikan tinggi. Sedari mula diperlukan proses pengidentifikasian dan perencanaan yang matang. Ini adalah sebuah proses yang panjang, dan hasilnya baru akan terlihat setelah beberapa dasawarsa. Piaget menyatakan bahwa anak-anak mengalami tahap perkembangan yang berubah-ubah. Setiap anak melalui proses pendewasaan dan kemudian mengembangkan kamampuan untuk berfikir sesuai tatanan moralitas yang tinggi (Piaget 1896 - 1980). Berdasarkan kajian Piaget ini, pendidikan antikorupsi harus sejalan dengan tingkat perkembangan anak. Selain Piaget, para ahli membagi tingkatan perkembangan individu secara beragam. Namun dalam konteks pendidikan, semua aspek perkembangan, antara lain perkembangan kognitif, iman, moral, dan lainnya menjadi pertimbangan dalam pendidikan antikorupsi (Hakim, 2012). Berikut kerangka dasar pendidikan antikorupsi yang disesuaikan dengan tingkat perkembangan anak (Manurung, 2012).

1. SD Kelas 1-3: Melalui pembiasaan dan implementasi langsung, anak-anak diperkenalkan pada aturan-aturan moral di rumah, sekolah dan di lingkungan seharihari. Proses pengenalan nilai-nilai ini juga dilakukan melalui kisah-kisah menginspirasi, permainan dan berbagai permainan dan simbol-simbol ketaatan.

2. SD Kelas 4-6: Menguatkan penyadaran dalam pembiasaan dan pengamalan tentang manfaat aturan bagi kehidupan, melingkupi kehidupan individu maupun dalam berinteraksi dengan lingkungan sosialnya.

3. SMP kelas 7-9: Menguatkan kebiasaan dan penerapan aturan secara konsisten dalam setiap hal dan situasi. Juga harus mampu berperan aktif dalam menerapkan aturan dalam kehidupan sosial.

4. SMA kelas 10-12: Menguatkan pembiasaan dan pengamalan aturan secara taat dan konsisten dalam segala kondisi di segala waktu dan dalam kondisi apapun. Sang remaja juga sudah mampu berinisiatif, dan berkomitmen untuk menegakkan prinsip dan menaati aturan di lingkungan yang lebih luas.

Remaja setelah SMA sudah diharapkan mampu berperan sebagai agen perubahan. Pengabdian masyarakat ini berupaya untuk mendukung kesadaran remaja pasca SMA untuk memahami persoalan bangsa akibat korupsi, dan turut serta 
secara aktif dalam upaya untuk mengeradikasi korupsi di Indonesia.

\section{Solusi Permasalahan}

Pendidikan anti korupsi harus ditanamkan secara terpadu mulai dari pendidikan dasar sampai perguruan tinggi. Pendidikan Anti Korupsi ini akan berpengaruh pada perkembangan psikologis siswa. Setidaknya terdapat dua tujuan yang ingin dicapai dari pendidikan anti korupsi ini. Pertama dari pendidikan ini diharapkan muncul semangat perjuangan menuju Indonesia bersih pada diri setiap anak bangsa. Melalui pendidikan ini, diharapkan semangat anti korupsi akan mengalir di dalam darah setiap generasi dan tercermin dalam perbuatan sehari-hari. Jika korupsi sudah dapat dicegah, maka proses pembangunan bangsa akan lebih efisien dan tidak menanggung beban kebocoran seperti yang selama ini terjadi. Kedua, tujuan pendidikan ini adalah agar para tunas bangsa menyadari bahwa pemberantasan korupsi bukan hanya tanggung jawab lembaga penegak hukum dan pemerintahan, melainkan menjadi tanggung jawab semua lapisan masyarakat, terlebih generasi muda dengan masa depan yang masih panjang.

Pola pendidikan yang sistematik akan mampu membuat siswa mengenal lebih dini hal-hal yang berkaitan dengan serba-serbi korupsi. Apa saja yang termasuk ke dalam tindak pidana korupsi, dan apa saja sangsi serta akibat korupsi kepada diri, keluarga, bangsa dan negara? Dari pemaparan ini diharapkan akan timbul kesadaran akan pentingnya generasi yang jujur dan berintegritas. Para tunas bangsa harus menyadari dan memahami bahaya korupsi, bentuk- bentuk korupsi dan tahu akan sanksi yang akan diterima jika melakukan korupsi. Program pendidikan ini dijalankan sebagai tindak lanjut upaya pencegahan tindak pidana korupsi sebagaimana diamanatkan oleh undang-undang untuk mengembangkan program pendidikan anti korupsi ke seluruh jenjang pendidikan (Badjuri, 2011). Program memberikan pendidikan Anti Korupsi ini dapat dimulai sejak usia dini kepada para siswa. Di sekolah dapat ditanamkan nilai nilai karakter Anti Korupsi pada anak-anak bangsa agar memiliki Jiwa Anti Korupsi. Perkenalan dan penjelasan atas 9 Nilai Nilai Karakter yang menjadi fondasi dari integritas ke arah budaya anti korupsi ini adalah:

- Jujur

- Mandiri

- Peduli

- Disiplin

- Tanggung Jawab

- Kerja Keras

- Sederhana

- Berani

- Adil

Karakter-karakter di atas ini bila secara konsisten terbentuk di dalam setiap individu anak dan remaja maka akan menjadi benteng anak bangsa untuk tidak melakukan perbuatan yang menyeleweng atau perbuatan korupsi jika mereka sudah dewasa kelak.

\section{METODA PELAKSANAAN}

Kegiatan gerakan pengabdian pada masyarakat ini dilakukan untuk membangkitkan kesadaran pentingnya membangun integritas dan menjadi agen perubahan. Proses pelatihan ini menggunakan pendekatan yang berorientasi partisipan. Partisipan semuanya aktif terlibat dalam memberikan pendapat baik melalui chat, melalui aplikasi menti-meter, melalui whiteboard pada platform zoom. Partisipan diminta memberi langsung ide untuk mengembangkan sembilan konsep dasar integritas. Contoh-contoh kasus serta penjelasan langsung ditampilkan di kelas virtual melalui fasilitas white board pada zoom, dan mahasiswa diminta mempraktekkan kiat-kiat hasil diskusi kelompok untuk dikampanyekan melalui sosial media.

Pelatihan virtual ini juga dilakukan dengan metoda Experiential Learning Discovery Journey, dimana semua peserta berperan aktif dan menemukan pembelajaran dari setiap proses serta proses pengajaran melalui contoh kasus dan permainan interaktif yang memotivasi. Dari program interaktif tersebut diperoleh wawasan yang berharga dan mendukung target yang ingin 
dicapai dalam pelatihan.

Metoda yang digunakan untuk melatih para"Change Maker" remaja adalah dengan menjelaskan proses pengembangan diri menjadi change maker yang menginspirasi secara holistik. Metodologi ini sangat menyeluruh dimulai dari pengenalan potensi diri, sebagai change maker baik dengan melakukan perubahan yang di dalam kendali diri maupun melalui kampanye yang mempengaruhi orang lain.

Para remaja yang mengikuti kegiatan abdimas (pengabdian masyarakat) ini diperkenalkan dengan konsep komitmen diri untuk menjadi agen perubahan. Pertama hal ini dapat dimulai dengan mempelajari hal-hal yang berada di dalam kendali diri (area of control) dan dapat dilakukan tanpa harus mengandalkan orang lain. Misalnya membentuk sikap yang menggambarkan sembilan karakter anti korupsi yaitu jujur, peduli, sederhana, tanggung jawab, kerja keras, mandiri, disiplin, berani serta adil melalui caracara yang dapat mereka contohkan dan lakukan sendiri. Kedua menggunakan pendekatan yang memperluas jangkauan pengaruh (area of influence). Dalam pendekatan ini para remaja dapat menjadi agen perubahan dengan gencar dan aktif mempengaruhi orang lain dan lingkungan agar juga dapat memperlihatkan karakter anti korupsi. Hal ini dapat dilakukan misalnya dengan melakukan kampanye melalui media massa. Para remaja dapat mempublikasikan postingan-postingan yang mengedukasi masyarakat mengenai gerakan anti korupsi. Di sekolah misalnya para siswa dapat berinisiatif untuk membentuk warung kejujuran, dan membina rganisasi remaja anti korupsi misalnya untuk membiasakan dan melatih kejujuran para siswa. Para remaja dapat berkolaborasi untuk melakukan kampanye anti korupsi untuk adik-adik di SMA, SMP maupun SD. Kedua pendekatan ini baik yang termasuk di dalam kendali diri sendiri (area of control), maupun dengan mempengaruhi orang lain (area of influence) (Naim, 2021) adalah hal-hal nyata yang dapat dilakukan remaja sebagai seorang agen perubahan.
Dalam pengabdian kepada masyarakat ini dengan menimbang keadaan Indonesia yang berada dalam kondisi pandemi COVID-19 ini maka pelatihan ini dilakukan secara virtual melalui ZOOM dengan susunan acara:

1. Konsep Membangun Kesadaran Anti Korupsi bagi Change Makers Remaja yang disampaikan oleh dosen Sekolah Tinggi Manajemen IPMI.

2. Contoh kasus melalui video dengan memutarkan video anti korupsi " tunas integritas bangsa ".

3. Talk show " menanamkan 9 nilai karakter anti korupsi " serta sesi tanya-jawab.

4. Permainan interaktif dengan menggunakan aplikasi "mentimeter" \& "kahoot "games.

5. Interaksi aktif peserta dalam Break Out rooms yang dibentuk sebanyak sembilan buah sesuai banyaknya karakter yang dibahas di dalam pelatihan abdimas ini.

6. Tiap grup menampilkan hasil kelompoknya melalui fitur White Board. Setiap grup melakukan diskusi bersama kelompok dan menyampaikan komitmen dari masing-masing kelompok.

7. Setiap komitmen dihimbau untuk di kampanyekan melalui sosial media dengan konsep menerapkan Area of Control (Wilayah dalam kendali) dan Area of Influence (Wilayah dalam pengaruh).

Melakukan survei "FEEDBACK" umpan balik dari peserta Webinar untuk mendapatkan kesannya terhadap acara pengabdian masyarakat ini.

Setelah melalui kegiatan no 1 sampai 4, peserta telah terbangkitkan motivasinya dan mulai memahami dampak negatif dari korupsi. Mereka diajak untuk berpartisipasi aktif dengan mengisi kolom-kolom hasil diskusi mengenai bagaimana mengembangkan karakter untuk mengembangkan integritas. Partisipan dibagi menjadi sembilan kelompok, dan masingmasing kelompok berdiskusi di dalam breakout room sesuai bahasan karakter yang berjumlah sembilan karakter. Para peserta sangat berperan aktif dan menuliskan komitmen grup mereka untuk mengembangkan karakter tersebut. Pada 
poin no lima ini terbukti mereka mampu merumuskan komitmen mereka untuk mengembangkan karkater integritas anti korupsi.

Proses pembelajaran bersifat aktif dan partisipan menjadi sentra perhatian utama. Proses Discovery Experiential Learning ini amat menstimulasi motivasi para peserta untuk terlibat secara totalitas di dalam proses pelatihan. Metoda pelatihan menggunakan berbagai aplikasi yang interaktif seperti mentimeter dan Kahoot serta whiteboard tools pada aplikasi zoom.

\section{HASIL DAN PEMBAHASAN}

Dari program talk show diberikan fakta-fakta yang membangkitkan kesadaran betapa dampak korupsi ini telah merusak tatanan kehidupan bermasyarakat. Berbagai fasilitas diselesaikan tanpa standar kualitas yang memadai. Masyarakat tidak dapat menikmati fasilitas sosial, kesehatan dan fasilitas publik lainnya secara memadai, karena tingginya kebocoran dana fasilitas umum akibat praktek budaya korupsi ini. Peserta diberikan pemahaman bahwa merubah budaya korupsi ini adalah tanggung jawab semua orang. Setiap insan termasuk tunas bangsa harus bahu membahu untuk memulai sebuah perubahan. Hal ini harus dimulai dari diri sendiri dan dilakukan dengan mengingatkan satu sama lain akan pentingnya gerakan anti korupsi untuk masa depan Indonesia yang lebih baik.

\section{Mentimeter}

Keterlibatan partisipan dilakukan secara maksimal dengan memanfaatkan perangkat aplikasi yang tersedia secara online. Salah satu yang digunakan adalah aplikasi mentimeter. Aplikasi ini mampu untuk menggalang pendapat para partisipan dan memperlihatkan kecenderungan dari jawaban tersebut melalui Word Cloud.

Sebagai contoh pada saat ditanyakan mengenai korupsi maka sebagian besar mengatakan bahwa itu adalah aksi kejahatan, tindak yang tidak jujur, merugikan negara dan tanggapantanggapan lainnya. Dengan melihat ukuran dari penulisan pada word cloud akan didapat ideide paling dominan apa saja yang muncul, seperti yang terlihat pada gambar 1 .

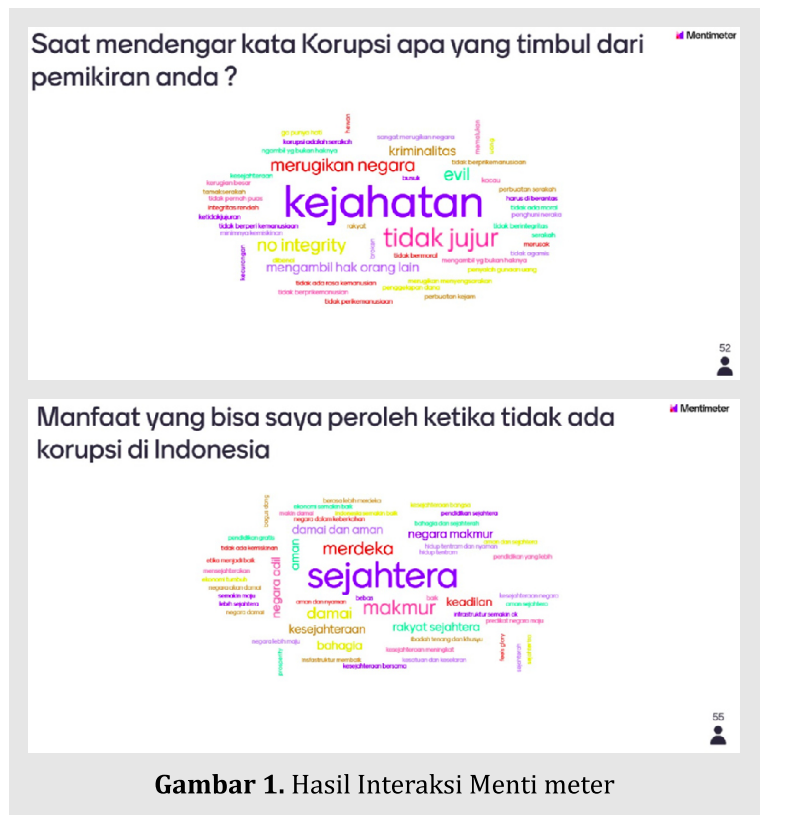

Dari hasil mentimeter ini, sudah diperoleh gambaran bahwa para partisipan yakin penanggulangan korupsi ini amat penting untuk mencapai tujuan masyarakat yang sejahtera. Secara proporsional terlihat bahwa partisipan bersepakat bahwa eradikasi korupsi di Indonesia adalah suatu hal yang mutlak harus dilakukan.

\section{Permainan Kahoot yang Membangkitkan Motivasi dan Pemahaman}

Agar para partisipan memusatkan perhatiannya pada materi yang dibahas maka diberikan suatu permainan cerdas cermat dengan menggunakan aplikasi Kahoot. Bagi para pemenang juga disediakan hadiahnya. Melalui Kahoot ini semua peserta berlomba-lomba dengan antusias menjawab pertanyaan mengenai karakterkarakter yang membangun integritas. Di akhir peserta dengan nilai tertinggi mendapatkan hadiah untuk membangkitkan semangat mereka untuk menjadi change maker anti korupsi. Mereka akan memposting pesan anti korupsi di sosial media dan menyebarkan gerakan ini secara getok tular. 


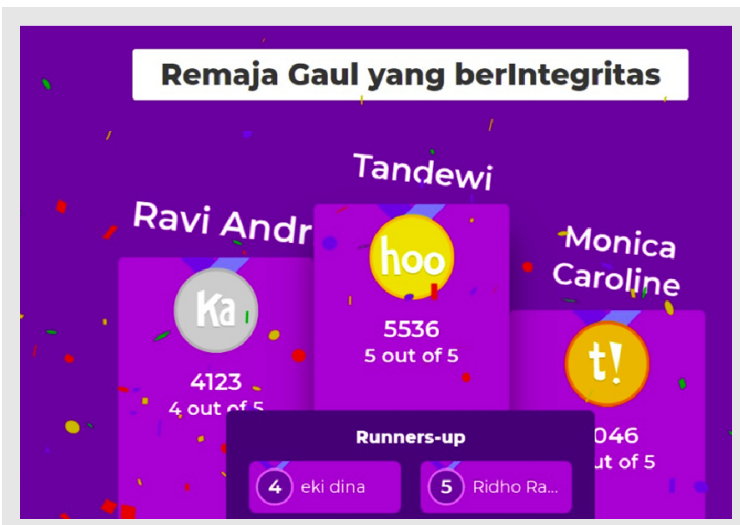

Gambar 2. Pelatihan dilakukan melalui proses permainan yang menunjang tujuan pelatihan

\section{Diskusi Kelompok melalui Fitur Breakout Room}

Agar peserta berinteraksi dengan aktif, maka dibentuk sembilan ruang breakout room untuk membahas bagaimana membangun komitmen dari masing-masing karakter dasar integritas. Para peserta dibagi menjadi 9 group sesuai nilai karakter Anti korupsi. Para fasilitator meminta komitmen para tunas bangsa dalam mengasah perwujudan nilai karakter Anti Korupsi. Grup pertama mendiskusikan kejujuran, kedua mendiskusikan kepedulian, dan berikutnya masing-masing grup membahas karakter mandiri, disiplin, tanggung jawab, kerja keras, sederhana, berani dan adil. Berikut adalah hasil diskusi dari ke sembilan kelompok.

Interaksi dilakukan melalui fitur white board dalam aplikasi zoom. Setiap kelompok secara simultan menampilkan hasil diskusi kelompoknya. Berikut adalah daftar dari hasil diskusi kelompok tersebut:

Team jujur:

1. Berani mengakui kesalahan.

2. Berani mengakui ketidakmampuan.

3. Mengatakan alasan yang sebenarnya.

4. Menjalankan amanah dengan baik.

5. Mengeluarkan pendapat sesuai dengan hati nurani.

6. Bersedia menceritakan yang sebenarnya saat diminta keterangan.

7. Tidak membuat cerita bohong.

8. Menempati janji.

9. Tidak memfitnah orang lain.
JUJUR

1. Berani mengakui kesalahan.

2. Berani mengakui ketidakmampuan.

3. Mengatakan alasan yang sebenarnya.

4. Menjalankan amanah dengan baik.

5. Mengeluarkan pendapat sesuai dengan hati nurani.

6. Bersedia menceritakan yang sebenarnya saat

diminta keterangan.

7. Tidak membuat cerita bohong.

8. Menepati janji.

9. Tidak memfitnah orang lain

DISIPLIN

1. Mengatur waktu dengan benar.

2. Skala prioritas.

3. Berhubungan dengan karakter

menerapkan ilmu pengetahuan sesuai

dengan bidang dan profesinya.
10. Menyampaikan titipan pesan dengan benar.

PEDULI

1. Penyuluhan kepada warga mengenai anti korupsi.

2. Mengingatkan jika ada penyimpangan, dan

jika ada indikasi terjadinya korupsi.

3. Kepedulian lebih besar terhadap tetangga.

Jiwa sosial yang tinggi.

4. Pajak dan wajib pajak melakukan kewajibannya,

pengembalian pajak kepada fasilitas umum

5. Transparansi dari hasil pungutan pajak.

6. Pelaporan jika terjadi pelanggaran, tertera

jelas kemana harus dilaporkan.

7. Mengawasi jalanya pembangunan dan melaporkan jika terjadi korupsi.

TANGGUNG JAWAB

1. Pelajar, menyelesaikan semua tugas dari guru.

2. Mahasiswa, menyelesaikan semua harus

dengan niat.

3. Bertanggung jawab pada diri sendiri.

4. Ikut mempengaruhi kelompoknya untuk

berpola pikir positif.

5. Harus mengutamakan prioritas dan hidup harus tolong menolong.

SEDERHANA

1. Tidak harus membeli barang yang bermerk.

2. Merubah mindset dan gaya hidup.

3. Naik transportasi umum (meminimalisisr pengeluaran).

4. Mengkonsumsi makanan yang tidak harus mahal.

5. Menerapkan gaya hidup sesuai kebutuhan.

6. Tidak bersifat konsumtif (membeli barang sesuai

kebutuhan bukan sesuai keinginan).

7. Tidak harus makan di mall (lebih baik dan

lebih terjamin makan makanan rumah)

8. Menerapkan time management yang baik (lebih produktif).
BERANI

1. Tegas dalam mengambil keputusan dan tidak ragu dalam mengambil keputusan tersebut.

2. Berani mengungkapkan [endapat apabila ada kejanggalan

3. Berani menyatakan kebenaran jika adanya penyimpangan dan berani menyatakannya dengan tegas.

4. Berani bertindak atau melawan bahaya atau kejahatan seperti memalak dan sebagainya dilihat dari situasi dan kondisi.

5. Berani bertanya dan menegur.

6. Berani bertanggung jawab.

7. Berani berkata tidak pada ajakan yang tidak

baik atau negative.

8. Berani berbuat baik terhadap sesama.
MANDIRI

1. Harus kreatif \& kerja keras.

2. Harus inovatif untuk mencari peluang

3. Meningkatkan ketrampilan/skill.

4. Berpikir terbuka mau mendengar.

5 . Selalu mau berubah/change.

KERJA KERAS

1. Menyelesaikan tugas kuliah.

2. Rajin belajar.

3. Membantu orang tua

ADIL

1. Tidak berpihak terhadap siapapun.

2. Apabila berkata selalu jujur.

3. Memberikan hak-hak kepada orang

lain dengan adil.

4. Perilaku yang dilakukan tidak menyimpang dari ajaran agama.

5. Menempatkan sesuatu dengan porsi dan keadaannya.

6. Mengadili suatu perkara hukum dengan sikap yang bijaksana dan keputusan yang seadil-adilnya. 
10. Menyampaikan titipan pesan dengan benar.

Peduli:

1. Penyuluhan kepada warga mengenai anti korupsi.

2. Mengingatkan jika ada peyimpangan, dan jika ada indikasi terjadinya korupsi.

3. Kepedulian lebih besar terhadap tetangga, Jiwa social yang tinggi.

4. Pajak dan wajib pajak melakukan kewajibannya, pengembalian pajak kepada fasilitas Umum.

5. Tranparansi dari hasil punguntan pajak.

6. Pelaporan jika terjadi pelanggaran, tertera jelas kemana harus dilaporkan.

7. Mengawasi jalannya pembangunan dan melaporkan jika terjadi korupsi.

Team Berani:

1. Tegas dalam mengambil keputusan dan tidak ragu dalam mengambil keputusan tersbut.

2. Berani mengungkapkan pendapat apabila ada kejanggalan.

3. Berani menyatakan kebenaran jika adanya penyimpangan dan berani menyatakannya dengan tegas.

4. Berani bertindak atau melawan bahaya atau kejahatan seperti memalak dan sebagainya dilihat dari situasi kondisi.

5. Berani bertanya dan menengur.

6. Berani bertanggung jawab .

7. Berani berkata tidak pada ajakan yang tidak baik atau negatif.

8. Berani berbuat baik terhadap sesama.

Tanggung Jawab:

1. Pelajar, menyelesaikan semua tugas dari guru.

2. Mahasiswa, menyelesaikan semua harus dengan niat.

3. Bertanggung jawab pada diri sendiri.

4. Ikut mempengaruhi kelompoknya untuk berpola pikir positif.

5. Harus mengutamakan prioritas dan hidup harus tolong menolong.

Team Sederhana:

1. Tidak harus membeli barang yang bermerk.

2. Merubah mindset dan gaya hidup.
3. Naik transportasi umum (meminimalisir pengeluaran).

4. Mengkonsumsi makanan yang tidak harus mahal.

5. Menerapkan gaya hidup sesuai kebutuhan.

6. Tidak bersifat konsumtif (membeli barang sesuai kebutuhan bukan sesuai keinginan).

7. Tidak harus makan di mall (lebih baik dan lebih terjamin makan makanan rumah).

8. Menerapkan time management yang baik (lebih produktif).

\section{Umpan Balik}

Untuk mendapatkan umpan balik dari kegiatan abdimas ini dilakukan survei secara singkat. Hasil umpan balik dari acara ini adalah sebagai berikut:

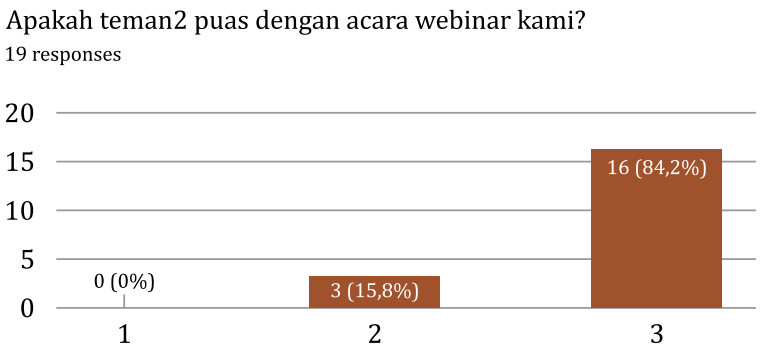

Apakah webinar kami menginspirasi teman2 sekalian? 19 responses

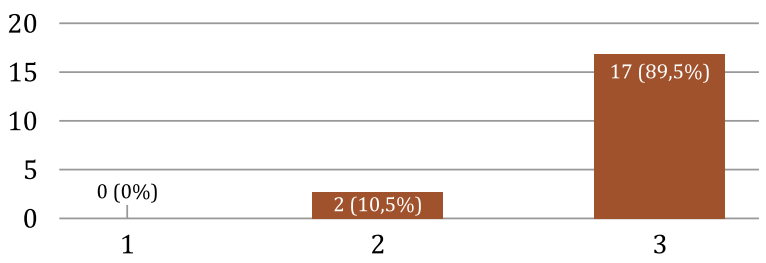

Kalau ada event seperti ini lagi, apakah teman 2 mau join? 19 responses

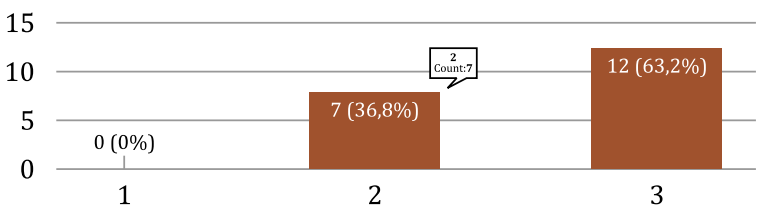

\section{KESIMPULAN DAN SARAN}

Pelatihan ini diadakan untuk membuka wawasan remaja untuk menjadi agen perubahan guna dapat turut serta mengatasi masalah negara yang dibelit kasus korupsi. Narasumber menyampaikan data-data miris mengenai dampak korupsi, yang diharapkan menyentuh perasaan para remaja sebagai partisipan acara ini. Pada sesi interaksi, 
remaja diberikan kesempatan untuk menunjukkan komitmennya dalam membentuk karakter anti korupsi. Dan terlihat bahwa mereka sangat bersemangat serta mampu merumuskan langkah-langkah nyata untuk mengembangkan sembilan karakter pendukung integritas.

\section{KESIMPULAN}

Para remaja memahami bahwa setiap orang mempunyai potensi untuk mempengaruhi lingkungan di sekitarnya melalui daerah kendali (area of control) dan daerah pengaruh (area of influence) dari mereka masing-masing. Secara ringkas hasil dari program pengabdian masyarakat ini adalah:

- Tunas bangsa yang sadar dan menjunjung integritas, sudah seharusnya bergerak bukan hanya dengan sekedar kata, tetapi dengan aksi nyata, baik yang berada dalam kendali ataupun dalam pengaruh dari masing-masing remaja sebagai agen perubahan.

- Tunas bangsa sebagai agen perubahan dapat melakukan aksi nyata dengan memberikan percontohan secara ril dalam bentuk karakter jujur, peduli, sederhana, tanggung jawab, kerja keras, mandiri dan disiplin dan memberikan percontohan karakter yang membangun integratis guna memberantas korupsi di negeri ini.

- Tunas bangsa jangan hanya bisa mengeluh saja melihat praktek korupsi di negeri ini, tetapi remaja harus bisa menjadi pelaku dari perubahan itu sendiri. Perubahan itu dapat lahir dari tangan-tangan tunas bangsa yang cerdas dan berintegritas.

- Tunas bangsa adalah pemimpin masa depan yang akan meneruskan estafet perjalanan bangsa ini.

- Tunas bangsa yang cerdas dan berintegritas harusnya bisa menjadi teladan dan kebanggaan bagi bangsa tercinta Indonesia.

\section{SARAN}

Pemerintahan hendaknya bertindak tegas agar mampu menjadi suri tauladan sebagai aparat pemerintahan yang bersih. Sistem hendaknya dibuat transparan dan sedapat mungkin bersifat online agar meminimasi celah untuk melakukan korupsi. Gerakan anti korupsi seharusnya tidak hanya dilakukan oleh Komisi Pemberantasan Korupsi melainkan harus menjadi tanggung jawab setiap warga negara yang bertanggung jawab. Sistem Whistle Blower atau pengaduan atas kejadian serta perilaku korup, harus diterapkan secara simultan di semua lini baik di kantor pemerintahan maupun di kantor swasta.

Secara mikro, setiap insan yang peduli akan nasib bangsa ini terlebih insan yang bergerak di dunia pendidikan perlu melakukan pelatihan dan pembiasaan penerapan karakter anti korupsi dan membina integritas. Pelatihan ini membutuhkan pengulangan yang terus menerus, agar dapat membentuk suatu kebiasaan baru. Sebaiknya dibentuk aksi kegiatan yang dilakukan secara berkala untuk mengingatkan para remaja akan komitmen yang telah dibuatnya. Setelah menerapkan target-target dari komitmen masing-masing, partisipan diharapkan dapat melakukan self monitoring dan evaluasi mandiri. Saat pertemuan dan diskusi berikutnya dapat dilakukan berbagai proses "review" untuk membahas kendalakendala yang dijumpai serta melakukan upaya perbaikan. Para remaja juga diharapkan untuk terus memperbaharui komitmen untuk terus berlanjut menjadi role model serta mengkampanyekan pentingnya menerapkan karakter anti korupsi. 


\section{DAFTAR PUSTAKA}

Hakim, L. (2012). Model integrasi pendidikan anti korupsi dalam kurikulum pendidikan islam. Ta'lim: Jurnal Pendidikan Agama Islam, 10(2), 141-156.

Naim, Amelia (2021). Sustainability Mindset Experiential Learning: A Monograph. Penerbit AMNA.

Badjuri, A. (2011). Peranan Komisi Pemberantasan Korupsi (KPK) sebagai lembagaanti korupsi di indonesia. Jurnal Bisnis dan Ekonomi, 18(1).

Manurung, R. T. (2012). Pendidikan antikorupsi sebagai satuan pembelajaran berkarakter dan humanistik. Jurnal Sosioteknologi, 11(27), 227-239.

Soraya, I. (2015). MOTIVATIONAL STRATEGY IN TEACHING ANTI-CORRUPTION IN SCHOOLS. Demcracy and Accountability (ICoDA), 299.

Wijayanto, et.al, (2010). Korupsi Mengorupsi Indonesia. Jakarta : PT. Gramedia Pustaka Utama.

Naim, A., Daryanto, W., Zahirsjah, R., \& Yeung, S. The Importance of Workplace Spirituality toward Enhancing Organizational Commitment and Job Satisfaction: A Conceptual Work. Nabu Publications.

Indrajaya, A. N., Yeung, S., Daryanto, W. M., \& Sjahrifa, C. (2019). The Conceptual Model ofSpiritual Leadership and Spirit at Work as Organizational and Individual Capabilities in Supporting Organizational Commitment and Job Satisfaction.

Naim, Amelia (2020).Kiat Menjadi Pembicara yang Menginspirasi. AMNA publisher. 